\title{
Organizational communication and corporate social responsibility. Case study: Romanian vs. International CSR
}

\author{
Luchenciuc Elena-Georgiana \\ luchenciuc.elena@yahoo.com \\ Prof. univ. dr. habil. Mihaela Rus \\ "Ovidius" University of Constanta, Romania. \\ psiholog_m@yahoo.com
}

Assist. Prof. PhD. Tănase Tasențe

"Ovidius" University of Constanta, Romania

office@pluscommunication.eu

\begin{abstract}
When we say "Organizational communication", we think, unconsciously, about organizations and how they are influenced by the effectiveness of communication both between team members and the external environment. Because the world revolves around ideas, concepts and communication strategies well developed for the purpose of informing, helping or even manipulating local and global communities, the paper will emphasize the importance of Corporate Social Responsibility (CSR) campaigns and how they influence the environment in the context of sustainable development, various categories of public or the image gained from such an initiative as they may represent a smart strategy to repair a stained name. To emphasize the importance of CSR, we will present some campaigns initiated by an the organization of the food and drink industry, both in Romania and internationally, between 2016-2018. Through this research, we set out to identify the main social responsibility campaigns of the organization, the main areas of action of the social responsibility campaigns and to establish comparative analysis between the particularities of the CSR campaigns in Romania and internationally.
\end{abstract}

Keywords. Corporate social responsibility, organizational communication, CSR

\section{Introduction}

As communication is one of the most important aspects of daily life, I have chosen, in this paper, to highlight its importance in organizations and how it can influence the results obtained in the projects carried out both at public and private level.

Regardless of institution, regardless of organization, regardless of group, the team is based on the results obtained from the hard work of a group of people who share the same interests and whose results could not have existed without an effective communication based on respect, trust and civic spirit. When we say "Organizational communication", we think, unconsciously, about organizations and how they are influenced by the effectiveness of 
communication both between team members and the external environment. Because the world revolves around ideas, concepts and communication strategies well developed for the purpose of informing, helping or even manipulating local and global communities, the paper will emphasize the importance of Corporate Social Responsibility (CSR) campaigns and how they influence the environment in the context of sustainable development, various categories of public or the image gained from such an initiative as they may represent a smart strategy to repair a stained name.

\section{Organizational communication - theoretical approaches}

In an organization, lack of communication can lead to chaos, as the multitude of goals, tasks, interests, human relationships are the main factors that can destabilize the entire management process and the collective climate. Thus, in the specialized literature, communication has been defined as "a simple fact: by practicing it, the man tries to establish with a person a relationship through which information, ideas, attitudes can be disseminated".

Communication is the main weapon in an organization, because it makes it possible both to exchange messages between people, to transmit information, thoughts and feelings, and to achieve agreement or disagreement, manifestation and imposition of power, negotiation and consensus.

In an organization, communication plays a major role in completing both the individual and collective tasks of its members. The lack of communication in a group is like salt in the food, without taste. Effective communication "occurs when the right people receive the right information in time" (Cândea, 1996) which leads to the need for a basic skill for a good manager, that is, to represent a good communicator.

Organizational communication is present on all hierarchical levels, at all levels of management, whether horizontal or vertical, it is indispensable for the achievement of goals, tasks or projects, individual or collective.

Despite the complexity and multiple meanings that communication sciences have, of any kind, one can simplify them, understanding first and foremost the stages that communication has in any group or organization. The communication presents two significant stages: (1) The first stage - Transmission of information, ideas, thoughts or orders of the receiver to a transmitter. This stage involves two mechanisms: Coding and transmission. (2) Second stage - Receiving the message by the receiver and transforming it into a transmitter, ie reception, decoding and response.

\section{The concept of corporate social responsibility}

The first definition of the concept appeared around 1950 from the so-called "parent of social responsibility", Howard Bower who defined CSR as follows: "the obligations of business people to follow those policies, to make those decisions, or to follow those directions that are agreed in terms of values and objectives by our society". The term "corporate marketing" was introduced by Kotler to define social responsibility in the Harvard Business Review magazine from 1972. He wanted to inform those in the field of marketing that the long-term welfare of the consumer is as important as meeting the needs. and maximizing profit. Kotler also returns in 2000 with a new definition based on the implementation of the concept on a larger scale, reaching not only to challenge the well-being of consumers, but of the whole society.

Over time, CSR acquires several definitions, such as:

- "a commitment that contributes to the well-being of the community through its own business practices and through its contribution to the company's resources" (Kotler, Lee, 2005) 
- "the process by which the managers of an organization think and discuss the relationships with the stakeholders as well as their roles in relation to the common good" (Basu, Pallazo, 2008)

- "the continuous commitment of the business to behave ethically and to contribute to the economic development, improving the quality of life of the workforce and that of the community" (Watts, Holmes, 2003)

- "it is clear that most authors want to say that corporate social responsibility includes behaviors and actions beyond simply realizing the profits that serve to improve social conditions and individuals within that society" (Mahon. McGowan, 1991)

In the development of a company there is a cycle based on three types of objectives: (1) the economic objective, (2) the ecological objective, (3) the social objective. We could say that a CSR campaign is a voluntary activity of a company in order to find the best solutions for the problems related to the environment or the community of which it is part. These campaigns involve some costs but can make a long-term profit through a good promotion strategy and a desire for development.

According to Tasente si Ciacu (2013), "social responsibility has become an essential element not only in raising the image capital or increasing the corporate reputation, but also for the involvement of society in activities aimed at the common interest". In their paper entitled "The impact of social responsibility of corporations on marketing from Romania", they have stated that the CSR in Romania is still growing and there is greater involvement in this area of the multinational companies but also for the local companies. too. The Romanian companies use CSR as a tactical tool and, therefore, most CSR projects in Romania are shortterm. Media and NGOs are not all too active in promoting this concept, at the government level, CSR strategy has been mostly imported from the EU" (Tasente, Ciacu, 2013).

\section{CSR, in Romania and internationally}

Research objectives

O1: Identification of the main social responsibility campaigns of an organization of the food and drink industry

O2: Identification of the main areas of action of the social responsibility campaigns

O3: Comparative analysis between the particularities of the CSR campaigns in Romania and internationally

To achieve the objectives of our research, we will use both quantitative and quality methods. Thus, we will analyze the CSR campaigns conducted by the organization, in Romania, but also internationally, between 2006 and 2018.

\section{The main CSR activities undertaken by the organization in Romania \\ A. "Hagi" Cup}

Starting with 2000 , the company is starting to organize a competition, the only childrens football tournament between ten and twelve years old. A year later, our country begins to participate in this movement supported by FIFA. "Believe in your dream!" is the motto of this event, attended by over two million children from all over the world, following the winning teams from each country to compete in the International Grand Final, inaugurated by Zinedine Zidane, the Ambassador of the Cup. In 2010 the company and Gheorghe Hagi (known as "the best Romanian footballer of all time") concluded a partnership to organize the competition that leads to the renaming of the event in the event, named after the official ambassador for Romania. The event is a unique experience for children and a way to learn about competition, fair play and teamwork. They also have the opportunity to learn about the importance of sport for health and a balanced lifestyle. 


\section{B. Smile for Romania}

Since the first days of organization's operation, the general manager of the organization stated that "a company exists and lasts only because it brings value to the whole society". On this principle the organization community was formed and extended to Romania where it managed, for seven years, to support the project "Smile for the future" in order to improve the chances of survival of cancer patients. The company has helped to increase the quality of life of the little ones, as well as to detect the disease from the first symptoms. With 200,000 Euros invested, the company together with the main oncopediatrics centers in Romania, the Romanian Society of Pediatric Hematology and other non-governmental organizations, such as the Little People Association, the Pavel Association, the Romanian Cancer Society or the Sebastian Foundation, the "Smile for the Future" campaign it was a success that led to the creation of the national registry of childhood cancer cases and a complex educational system for doctors, and the children also benefited from psycho-social support.

\section{One yogurt a day, your health is keeping you}

The company's main objective is to support people in choosing a healthier lifestyle based on sport and a balanced diet that should be brought to the notice of children from the earliest age, as this can contribute to their long-term development. The company's factory in Bucharest is visited every year by over 1000 children who have the opportunity to learn how milk is made but also about its importance for our health. The organization is also involved in schools with interactive presentations on what healthy nutrition means, especially within the "Week Otherwise" program, at the initiative of teachers or parents. According to the study "Eating habits" carried out by the Romanian Institute of Evaluation and Strategy in 2013, 9 out of 10 Romanians eat unhealthy and have a sedentary lifestyle, which has led to various health problems such as obesity, diabetes or cardiovascular diseases. One of the solutions that the organization has thought of bringing to the fore, not very expensive, is the daily consumption of yogurt. It contains much of the valuable proteins needed by the body, as well as calcium or other minerals and vitamins that help raise children and maintain health throughout their lives. On this aspect, Romania is the last place in terms of consumption of yogurt, at European level.

\section{The main CSR activities worldwide managed by the organization}

\section{A. Breastfeeding}

Internationally, the organization is the only company that supports the actions of the WHO Code ${ }^{*}$ on exclusive breastfeeding of children up to six months and its continuation in the next two years with the safe introduction of complementary foods. Also, the company helps future moms with all kinds of campaigns in order to optimally feed the little ones both during pregnancy and after birth. This type of campaign also exists in Romania, the company being a supporter of the SAMAS Association. SAMAS Association is a non-profit organization, which has developed the only national network of perinatal educators (among nurses and midwives), specializing in prenatal and postnatal education, mother and child nutrition. The company has strict policies regarding advertising and promotion of substitutes for breast milk in order to avoid negative influence of mothers. In countries with high mortality, the company has voluntarily extended its policies, up to twelve months of compulsory breastfeeding of infants, often contrary to local law. A key factor of the Company's Global Parental Policy is the protection of the employees against discrimination in the workplace. No employee should feel embarrassed to announce a pregnancy or be discriminated against on the grounds of motherhood, paternity or adoption. To ensure that the 
company's principles of a healthy lifestyle are important and apply to all CSR campaigns, each year the company selects three countries to send an audit aimed at identifying the irregularities (if any) and for their correction.

\section{B. The Eve program}

The Eve program is a seminar based on the idea of being yourself and stimulating you through the best ways, improving your performance and making changes. The program was made at the initiative of some women, aware of the risks they have when they want to move within a company. The program was launched in 2010 by the organization of the food and drink industry in partnership with other multinational companies, with 350 participants and speakers who spent three days discussing ideas. Since 2010, the organization has inspired over 3000 people, with different nationalities but with common interests. The seminars are held both individually and organizationally, always being held in Evian, France, but, to help and support women in Africa, the company also organizes a second edition of the annual seminar, held in 2013 in Dakar (Senegal).

\section{Water management}

The organization is one of the most important bottled water companies in the world. Worldwide, both people and food, depend on the quality of water that the company does all it can to protect it, being one of the most important resources. Researchers say that by 2030, global demand for water will increase by over $40 \%$ compared to the present and over half of the world's population will live in areas with stressed water (water-stressed $=$ Water stress is a term used to describe when demand for water is greater than the amount of water available at a certain period in time) which is why the company focuses on less risky areas, adopting solutions locally for quality, quantity and access to water.

The organization focuses on strategies and partnerships, the main pawns being:

1. Water reduction in various operations, as the company has direct control over the amount of water it consumes in various operations.

2. Protecting water ecosystems

3. Promote agricultural practices oriented towards water conservation as agriculture accounts for almost $70 \%$ of the global water consumption.

4. Increased access to drinking water, especially in areas with a high deficit

\section{Conclusions}

No company that respects itself and respects its public - whether it is a public or private company - will not be able to enjoy satisfactory results without the support pillar being an efficient communication, in close connection with today's modern means. they come to the support of the organizations and that offer them the necessary resources to reach the various objectives.

Known in Romania, but also abroad, the company enjoys a positive reputation among the distribution of dairy products and a continuous involvement in various activities, campaigns and strategies in support of long-term development. However, an important thing to keep in mind when carrying a big brand is to never make people forget about it, which the organization has taken great care of. The population has not come to identify the company just as that classic yogurt eaten or drunk on the run when you don't know what to choose or in some cases, mentioning the fruit one because of its delicious taste, but the company is up to the standards international in terms of CSR campaigns and the desire to promote a healthy 
lifestyle for all age or gender categories, coming to support people with modern strategies and innovative ideas in order to establish a prosperous future for future generations.

As mentioned at the beginning of the paper, communication is the basic pillar in human relations, but also in organizations. A company must always keep its audience up to date with all its achievements, especially when discussing a brand that contributes to longterm development. The company is involved with body and soul in any activity they participate in, but if they don't offer any information about them, people will think the organization doesn't care about them. Maybe they will continue to drink their yogurt but they will not feel anything but that feeling of satiety when they throw the packaging into the garbage.

Those who watch TV regularly remember that spot that reads "For your health, consume at least two liters of water a day". Water, one of the most important resources for humans, is also produced by the monitored organization, a company unknown $90 \%$ of the study participants. At the international level, the organization is known for its permanent involvement in activities related to the environment, while in Romania, it focuses more on people and their health. Does it not depend on the health of the people and the environment in which they live? Once a sick patient has been healed, returned to the same environment in which he lived, there is a $70 \%$ chance that he will get sick again.

\section{References}

[1] Cândea, R. (1996). Comunicarea managerială, Bucureşti. Editura Expert. 182-183

[2] Kotler, P., Lee, N. (2005). Corporate Social Responsability. Business \& Economics

[3] Basu, K., Palazzo, G. (2008). Corporate Social Responsibility: A Process Model of Sensemaking. The Academy of Management Review. Vol. 33, No. 1 (Jan., 2008), pp. $122-136$

[4] Rus, M., Sandu, M.L. (2015). Elemente de statistică aplicată. Ediție revizuită și adăugită, Editura Pro Universitaria București

[5] Rus, M., Banariu. M.G., Sandu, M.L. (2015). Comportamentul simulat. O abordare interdisciplinară, Editura Pro Universitaria, București

[6] Tasente, T., Ciacu, N. (2013). The impact of Social Responsability of Corporations upon the marketing from Romania. Sovremennaa Ekonomika: Problemy, Tendencii, Perspektivy, vol. 9 (2), 2013 